\title{
The practical theologian as decentred but influential facilitator
}

\begin{abstract}
Authors:
H. Elmo Pienaar ${ }^{1}$

Julian C. Müller ${ }^{1}$

\section{Affiliations:}

${ }^{1}$ Department of Practical Theology, University of

Pretoria, South Africa

Note:

The article was in part presented at the 'Joint Conference of academic societies in the fields of Religion and Theology', 18-22 June 2012 , in Pietermaritzburg, South Africa.

This article is published in the section Practical Theology of the Society for Practical Theology in South Africa.

\section{Correspondence to:} Elmo Pienaar

Email:

elmo.pienaar@up.ac.za

\section{Postal address:}

Faculty of Theology, University of Pretoria, Lynnwood Road, 0083 Hatfield, Pretoria,

South Africa

Dates:

Received: 27 July 2012 Accepted: 04 Oct. 2012 Published: 05 Dec. 2012

How to cite this article: Pienaar, H.E. \& Müller, J.C., 2012, 'The practical theologian as decentred but influential facilitator', HTS Teologiese Studies/ Theological Studies 68(2), Art. \#1307, 10 pages. http:// dx.doi.org/10.4102/hts. v68i2.1307
\end{abstract}

C 2012. The Authors. Licensee: AOSIS OpenJournals. This work is licensed under the Creative Commons Attribution License.
Since the 1970s along with the resurgence in practical philosophy new possibilities opened up in our understanding of the place for and purpose of practical theology. The repositioning of practical theology as a fully worthy discipline was important to find its voice amongst theological peer disciplines. Against this background, it was argued that the full measure of what the discipline can contribute, especially outside of the ministry context, has not yet been fully developed or practiced. Towards this end the presentation's main contention was put forward, in that it is vital for the practical theologian to take up a role of an inscribed facilitator. It signifies a shift from practical theology to practical theologian and is exemplified by the practice of a facilitative approach in, and to practical theology.

\section{Introduction}

This article fits into the larger genre of elsewhere (Pienaar 2012) referred to as practical theological facilitation. In what way? In that the concepts used, such as, inscribed, decentred, and a particular understanding of what it means to be informed, qualify aspects of facilitation that we deem important.

With reference to Tracy's (cf. 1998) audiences of practical theology, if practical theology was to effectively engage different audiences, specially a public audience then the rationale for engagement needs credibility. The assumed lack of credibility, which relates to multifarious aspects, such as, the churches role in apartheid in the South-African context to the problematic of propositional approaches in a postmodern climate cannot be argued here.

Accepting the aforementioned background thesis, the concern of this article is with furthering the kind of approach and interdisciplinary dialogue that might most credibly engage, particularly, the public audience. Doing so from a practical theological perspective; or rather, a practical theology that finds it useful, effective and rigorous to draw from practical philosophy, storied practical theology, and some important concepts and elements of both disciplines' development and practice.

Consequently, two voices are invoked: that of practical theology and of facilitation. In the context of practical theology the notion of facilitation is one that is new - at least in view of its formal appropriation that it receives here. After clarifying the notion of facilitation, so as to gain an understanding of how these two fields are brought together, we offer some remarks on the development and influences of both these fields. This will be our first section and it will leave us is with an emphasis on the importance of both the individual and the collective.

The middle section, namely, 'Storied practical theology', will pick up on the individual dimension, particularly so from a narrative point of view and with specific reference to practical theology.

The last section, that is, 'The inscribed facilitator', serves to relate the ideas of the middle section on practical theology back into the framework of facilitation.

Whilst some of the concepts are only referred to explicitly later in the article they are embedded in the disciplines and particular traditions we rely on. We refer to them shortly. To be inscribed asks of us as facilitators and/ or practical theologians to realise that we are not bringing a clean slate to our engagement with people, and indeed that it is not possible to wipe that slate. The reason being that our participation is informed by familial, religio-cultural and other influences, might they be perceived as positive or negative. As researchers, counsellors, coaches, facilitators we are sensitive to power discourses and what we, as the so called professionals, might represent. So although we cannot be without influence, we opt for a decentred position that still affords us the opportunity to share or offer our stories in the transitional space of facilitation. 
Thus, the concepts of decentred, having unavoidable influence, being informed or inscribed are expressed in the meaning of what the role of facilitation or storied practical theology stands for. Consequently this article is as much about these concepts as they are about asking questions about the theory and practice of practical theology. An important contribution however lies in bringing these concepts to dialogue across disciplines.

\section{Out of the blocks with facilitation}

The fact that different people have different experiential situations because they come from different traditions, and in addition commit themselves to different research traditions, makes it normal, natural, and rational that they should proceed differently in cognitive, evaluative and practical matters. (Van Huyssteen 2000:437)

Given this diversity, how do these people collaborate or live life together, or partake in conversation in a way that is sensible, meaningful, ethical in all aspects, and make worthwhile decisions en route to achieve what they initially set out or hope to achieve? This is the task of the facilitator.

For Bens (2005), who is a professional practitioner facilitator (not a theologian), a facilitator is a person who:

contributes structure and process to interactions so groups are able to function effectively and make high-quality decisions. A helper and enabler whose goal is to support others as they pursue their objectives. (p. 5)

The way that we employ the notion of facilitation, and later that of rationality is wider than for both Bens' (2005) and Van Huyssteen's (1999, 2006a) $)^{1}$ use thereof: apart from widening the scope of these concepts we also differentiate between semi-formal and formal ways of appropriating facilitation. Let us explain.

Firstly, we use the word facilitation as both a metaphor and a role that loosely corresponds with a semi-formal and formal understanding of facilitation. For the purpose of this article we will not adhere strictly to keeping such a distinction but note that this differentiation widens the scope already. It is wider in that it can be used to distinguish between facilitative practical theology (a predominantly metaphor-informed way to pursue practical theology), and in what might be referred to as practical theological facilitation (predominantly practice and role-informed, as in professional facilitation). With Van Huyssteen, situated in the discipline of systematic theology ${ }^{2}$, his use of facilitation pertains particularly to the academic interdisciplinary dialogue between theology and science and specifically so with reference to postfoundational rationality. As such, the word facilitation is used as a verb ${ }^{3}$ and not as we understand it also, a role. To illustrate Van Huyssteen's (1999) use as a verb:

\section{Specific references are included in footnote 4}

2.See for instance his earlier writings, from the mid-1980s, explicitly approached from a systematic theological perspective (cf. Van Huyssteen n.d.).

3.The following specific references from two of Van Huyssteen's works could be consulted in this regard. It illustrates that he mainly employs the concept of facilitation in verb format, not a formal role. See Alone in the world? (2006a:19, 20, $22,26,41,108,114,300)$, and The shaping of rationality $(1999: 4,5,187,195,219)$.
Rationality thus clearly entails an unavoidable investment in the interest of others. Because our epistemic communities never exist in complete isolation from one another, it will be important to realize that an adequately contextualized notion of rationality is necessary to facilitate intersubjective, cross-disciplinary conversation. (p. 153)

Our view encapsulates that of Van Huyssteen, but as practical theologians, facilitation serves to engage not only academia (in the said cross-disciplinary conversation) - as one of Tracy's audiences of practical theology (1998) - but also the ministry context and then especially the public dimension of society as an audience.

Although we will need to comment more elsewhere, rationality also lies close to the heart of facilitation since the facilitator will have diverse rationalities to account for in facilitation. One has to view rationality in a wider framework to clarify what we see as part of the task of the facilitator. A broader understanding might include Browning's (1991) views on practical reasoning, renowned creative thought leader, De Bono's (n.d.) work on Lateral Thinking (1973) and Six Thinking Hats (1999) and any means by which a person or organisation makes sense of the world, particularly in respect of its everyday living where decisions are made and our narratives are performed. When acknowledging different rationalities and in view of the actual professional practice (i.e. role) of facilitation, the use of the word facilitation cannot just be used colloquially.

Secondly, in respect of the professional facilitation role, as with Bens (2005): the understanding of the facilitative role can be interpreted wider than Bens' description of professional facilitation. It could include a consulting role (particularly a facilitative-consulting role). Consequently, in underscoring facilitative practice in the context of consulting, it resonates with the gist of what practitioner facilitation and narrative practice are about. Furthermore, following the differentiation of Kiiti and Nielsen (1999) between facilitation and advocacy, we connect narrative ideas to a facilitative approach whilst advocative voices relate more to conventional consulting practice. Widening the conceptual framework could therefore involve that facilitation has a role to play in a broader context of advocacy. Yet advocating in the context of facilitation is more contentious.

The idea of consulting also implies that the kind of dialogue that seeks facilitation is not restricted to in-the-moment dialogue; in this sense the conceptual framework is also widened. It takes into account ecological, political, social and other dialogues that take shape on an elaborate scale and different platforms. Relating to these platforms, dialogue might also account for the influence of media such as television, newspapers and so forth as part of the voices or texts in the dialogue.

Although overlap exists between public theology and what we are discussing in terms of the public dimension of practical theological facilitation, the focus is notably different. Firstly, the angle is particularly one of practical theology, in 
addition informed by postfoundational or post-structural accents therein (cf. Müller 2004, 2011b). Furthermore, although a public dimension is unavoidable the emphasis lies greatly with the means as informed by epistemology and methodology, and less on the end (being restricted to a certain area such as the imperative of the public domain). Rather, a specific area of interest is something that will stem from the way in which the particular individual (practical theologian and/or facilitator) is inscribed or informed. This entails that neither the facilitator nor the practical theologian as facilitator can dissociate themselves from their culture and experiences. Thus, epistemologically speaking, whilst a person in roles such as, for example, facilitation, coaching, counselling, and research, cannot be without influence, an intentional decentred role is adopted.

The contexts of, and answers to, the following questions serve to illustrate something of the scope of a facilitative approach in and to, practical theology. The 'decentredinfluential' facilitator (and other words that we refer to, such as the 'inscribed' facilitator), will ask questions such as the following: where is, or where should dialogue be taking place? Whose voices are, or should be heard in this dialogue? What inhibits, or what will allow this dialogue to take shape? How might this dialogue take shape (both on wider platforms and in the moment)? What is my own role in this dialogue?

We have said something about the larger conceptual framework in which we place facilitation in order to create a preliminary shared understanding. It seems helpful now to elaborate on why practical theology and facilitation are thought of as meaningful interdisciplinary partners. To do so we present only some of the informing developments and influences of both.

\section{Thoughts on the development of practical theology \\ Four part development}

De Roest (1998:26-27) cursorily tracks the agenda of practical theology. He mentions that there was first a focus on ministry and leadership as it relates to the clerical paradigm with subdisciplines divided along the lines of the activities of the pastor. Secondly, he distinguishes a movement from the 1950s that gives prominence to the functions of the church as a whole as it finds expression in ecclesiology and church development. Then, in the third instance, came a broadening of focus in liberation theology as a form of practical theology. Herein the function of the church is directed towards serving society, in that it moves away from ecclesiocentrism. Fourthly, and lastly, a still wider net is cast that brings into focus the life of individual believers, of lay people, which directs the attention to the individual learner, hearer, emphasising a search for a meaningful life.

The above-mentioned last stated focus pertaining to the individual, relates particularly to a facilitative approach in, and to practical theology, which forms the larger context of this article. Said context is, however, still in development. With that being the case it is not possible to elaborate sufficiently on all the arguments employed in this article that rely to different extents on said context. See in this regard Pienaar (2012), 'Overture to practical theological facilitation' that starts to explore what a facilitative approach in, and to, practical theology could entail.

Of the four part development that De Roest (1998) touches on, the view that we emphasise (one that is important to practical theological facilitation) is that of a shift to the individual, the person; but then also the person of the practical theologian (as opposed to what makes the discipline of practical theology coherent and also as opposed to merely a shift toward lay people, believers and so forth, as indicative of the shift to the individual). Herein the life of the practical theologian becomes an artwork in the ecotone (cf. section on 'Storied Practical Theology').

Yet this is not where we end. It is not about setting the individual (lay person, or specifically the practical theologian) as the agenda or the object of study, but rather what happens in the space between one individual and another or the collective.

\section{Toward practice and interpretation}

The notions of practice and interpretation resonate strongly with facilitation. One of the practices of facilitation has to do with how people make decisions in various practice oriented contexts.

The idea of practice has a particular history in practical theology that is also relevant to facilitation. Emanating from the development of the agenda of practical theology, De Roest (1998:19) sees a gradual agreement amongst practical theologians to localise their point of departure in practice. A description that is therefore still useful is that of practical theology as a Handlungswissenschaft, meaning a science of action. Hereby normative prescription or theological description pave the way to a social-scientific description (De Roest 1998:20). De Roest is right to assert that this shift was gradual from the 1960s onwards (De Roest 1998:20), perhaps so since one has to remember that calling oneself a practical theologian was at one stage to invite scepticism and humiliation amongst the academic community and to an extent also one's theological colleagues (Browning 1991:3).

The growing awareness of this new kind of broadly defined agenda, of practice or action, was helped along to a great extent by the resurgence in the practical philosophies (Browning 1991:3). Browning was a pivotal contributor to the movement from pastoral theology - that fits roughly De Roest's second movement with the advent of the 20th century - to practical theology (Anderson 2001:25). Yet the distinction between practical theology, as opposed to theoretical theology was made already by Philip Marheineke (1780-1846) after which practical theology received its independent status (Anderson 2001:24). In that time the theory-praxis relation was the 
central focus although innovation was confined to the local congregation (Anderson 2001:25 - in accordance with De Roest's proposal (1998).

It is evident that Browning relied on what happened in practical philosophy at the time around the 1970s (cf. Browning 1983), to resituate the conceptualisation of the discipline to that of practical theology. Tracy (1994:134) also references the widespread recovery of practical philosophies, linking them to new practical theologies such as political oriented approaches. Even more significantly is that Tracy (1994:134) ties it together with a redefinition of hermeneutics, where the emphasis changes from text to discourse and from historical context to social location (with reference to gender, class, and race). Discourse and social location resonate strongly in turn with facilitation and as such this new hermeneutics (but also the earlier understanding thereof) is relevant to the dialogue between facilitation and practical theology.

The issues concerning practical philosophy are, for example, related to notions of freedom (will, autonomy), matters of practical reason (with respect to Kant this entails categorical imperatives, maxims, and laws), moral obligation (such as rights, duties, and virtues), and political obligation (such as property, trade, peace) (Westphal 2011). In our time, after World War II, matters of life and death (of practice), have turned philosophy's focus towards the practical (Toulmin 1988:343). After 1945, these matters related to nuclear war, medical technology, and the environment (Toulmin 1988:343). The surface questions to these relate to the significance of human life and our responsibilities to both humanity and nature (Toulmin 1988:343). With such topics and their deliberation, the reasoning is practical both in view of the subject matter - being action - but also practical in its consequence in that reflection moves people to act (Wallace 2009).

Browning (1991:3) implies that the rebirth of the practical philosophies signified that the epistemological climate has changed. The foremost contribution of this 'rebirth' to the larger climate change - and Tracy refers specially to theology (1994:75) - found expression in an interpretive turn. Not only, therefore, did the interlocution with the social sciences and practical philosophy underscore an agenda of practice, but it endowed us with an interpretive turn that reframed our epistemological awareness. This epistemological shift lies also at the heart of the kind of facilitative approach that we present. We certainly have our doubts about a kind of practical theological facilitation that might be pursued, which does not account for the epistemological climate change.

It is important to note that this epistemological change is not only an evolution of systems theory, but indeed a discontinuous paradigm, a different language (Freedman \& Combs 1996:14). To Freedman and Combs (1996:14), the interpretive turn and other concepts that relate to the epistemological climate change, such as post-structuralism, deconstructionism, and the new hermeneutics are encapsulated in the broad movement and/or consciousness of postmodernism.
The epistemological reframing happened to such an extent that, with for instance Clifford Geertz (the foremost anthropologist of his generation, 1936-2006), a major rethinking took shape on the boundaries between the social sciences and the humanities (White 2007:1187). In addition to Geertz (who was a key figure relating to the interpretive turn in the social sciences), Paul Ricoeur was also instrumental in 'finding a model of interpretation that links the hermeneutical perspective of the human sciences with the empirical perspective of the social sciences' (Anderson 2001:26). Something that cannot be described other than by saying it was a monumental shift to interpretation and the humanities, can also be seen in philosophy. Richard Rorty's development is particularly relevant. ${ }^{4}$ Niel Gross in his study of Rorty notes that Rorty had been a hardnosed analyst who engaged in the rarefied debates in the philosophy of mind (Gross 2008:4). Later on Rorty encouraged a "relaxed attitude" toward the question of logical rigor, to stop drawing arbitrary boundaries between philosophy and other humanities fields' (Gross 2008:4). Richard Rorty, to mention a most concrete example, left his post in the philosophy department at Princeton University to become a professor of humanities at Virginia (Robbins 2011:xv). This epistemological shift does not only relate to Rorty's personal development but has wider philosophical relevance. Vattimo (2011) explains:

Twentieth-century philosophy had once cherished a dream of becoming a rigorous science, a dream that ... had characterized positivism and phenomenology, respectively. But as Husserl put it, the dream was 'dreamed out' (ausgeträumt), it faded away, and with it the idea that philosophy ought to be a robust representation either of reality or, at any rate, of the modes in which we represent reality. (p. 2)

\section{Focus on the collective}

Mottier (2005:para. 9) notes that in qualitative research, different perspectives associated with the interpretive turn regard the social world not as 'a collection of external "facts", but as a subjectively experienced construct.' If by subjectively is meant individually, then there is still more that needs to be said. The epistemological, interpretive shift did not only leave us with an emphasis on the individual. Our view is that similar to what one might find with pertinent development in science from early modernisation to a scientific consciousness of later modernity, so also one might find a shift in consciousness from childhood - early postmodern consciousness (reality as individual construct) - to early adulthood (reality as social construct). De Roest was correct in his estimation of the agenda of practical theology at that time with an emphasis on the individual. He himself had then extended the focus to the collective (cf. De Roest 1998), which along with the notion of what it means to be an inscribed facilitator, is to us a central concern in facilitation. It seems then that something else - being mindful of the collective - started to happen that is of importance to a facilitative approach in, and to, practical theology. Deriving from the re-emergence of the practical philosophies, Browning (1991:3) points to a renewed interest 4.See Grippe (2006). 
in matters of practical reason, practical wisdom, phronesis, practice, praxis, justice, consensus, dialogue, conversation and communication. All of these, but perhaps most clearly the latter notions, relate to the collective.

The focus on the collective found particular expression in the 1990s: De Roest (1998:27) - drawing on Habermas' perspectives on discourse - extends the focus to the collective and communicative identity. Herein his work is aimed at communities, organisations, movements, groups or all those who, by having some kind of relationship to the person of Christ, are 'surprised at being together' as in the French expression he uses, bien etonnés de se trouver ensemble. Browning refers to philosophers who underscore the notion of tradition in the way that practical rationality works (1991:2). Herein our focus aligns. He is not only concerned with practical rationality of a person, he aims to answer two questions regarding communal ways of knowing: how are congregations both communities of memory and communities of practical reason? (cf. Browning 1991:3).

De Roest and Browning's focus on the collective is also relevant in view of what some facilitative practitioners believe. Hunter, Bailey and Taylor (1995:4), writing in the mid-1990s note that we (i.e. society) are on the forefront of what can be described as a quantum shift in human consciousness. By this they refer to a movement from individual personal development mindedness to group consciousness. They refer to this quantum leap as having been foreshadowed by family therapy, organisational development research and experience gained by living in communities. Practical theological academic preference for a coalescence of approaches and complementarity of methods were key phrases, also, in the 1990s, as noted by Dingemans (1996:91). It says something about the acknowledgement of different perspectives found in the collective. These approaches had taken the form of what Osmer (2011:3) refers to as the reflective equilibrium of the discipline, referring to practical theology's tasks of being descriptive-empirical, interpretive, normative and pragmatic with the relationship between them part of a hermeneutical circle (ed. Osmer \& Schweitzer 2003:1-5). One of the seminal works on narrative therapy, also published in the mid-1990s, namely, Narrative therapy. The social construction of preferred realities (1996), by Jill Freedman and Gene Combs, underscores the epistemological importance of social constructionism in the shaping of realities. Kenneth Gergen's landmark book on social constructionism appears late in the 1990s, and saw a revision in 2009. Although many influences informed what would later be known as practitioner facilitation the formalisation of the International Association of Facilitators came about only in 1994 (Hunter et al. 2007:316). By no means least important, one has to keep in mind that South Africa's first democratic election took place in 1994. From the interest in the democratic collective ensued phrases and concepts such as 'It takes a village to raise a child', 'I am because we are', Ubuntu culture, the Batho Pele (people first) principle, and so on.
More recently, Debray (2008), mentions his awareness of a backwards swing of the spiritual pendulum in history with the effect of an ancient sense of tribal grouping, 'by the revealed religions according to their natural, territorial inclination.' This, particularly as a consequence of 'spiritually empty economism of our prosperous liberal societies'; 'lack of freely granted civil religion'; 'the lack of agnostic spirituality'; and, 'the lack of credible political and social ethics' (Debray 2008:35).

\section{Thoughts regarding some of facilitation's influences The 'once upon a time'}

Group facilitation is said to have a rich history and many influences (Hunter et al. 2007:105). History and different cultures are filled with aspects of facilitation that were used by the wise of their time (Hogan 2005:256). She refers to Shamans, Inca people, Lao-tzu, Socrates, Buddha, Christ, and others (Hogan 2005:256). Doyle (2007:xiii) notes that Alaskan natives report of this kind of role in ancient times. With specific mention to consensus ${ }^{5}$ - it being a decisionmaking mode of facilitation - various forms of consensus were used by indigenous peoples at tribal councils and other deliberations (Hunter et al. 2007:20; Doyle 2007:xiii). Hunter et al. (2007:183-184) refer to still active indigenous consensusbuilding approaches with the Americas and what is called wisdom circles, and to traditional Maori decision-making characteristics.

\section{The 'not too long ago'}

In modern history, Hunter et al. (2007:183-196) cite many influences in an attempt to map the field of facilitation. Drawing on Hunter et al. (2007:183-196) we list a few examples consisting of people, concepts and movements showing towards the diverse influences of facilitation:

- The Quakers (i.e. the Religious Society of Friends) with whom consensus decision-making was a centrepiece from their inception in 1660.

- Kurt Lewin (who is regarded as one of the founders of social psychology and the person who coined the term 'action research'), who is associated with 'T-groups', and 'group work' that incorporates individual therapy.

- Carl Rodgers and 'encounter groups'.

- Will Schutz and 'open encounter' in the 1970s and 1980s.

- Jacob Moreno with 'psychodrama' and 'sociodrama'.

- Wilfred Bion and the 'Tavistock method', as it relates to group development

- Scott Peck on community building.

- Brian Standfield and the 'ICA Technology of Participation'.

- Fran Peavey, a social change activist associated with the group 'Heart Politics' and the development of 'strategic questioning'. The name of the group 'Heart Politics' is derived from Fran Peavey's book by the same name. From

5.Bear in mind that consensus does not necessarily entail that everyone must agree (Hunter et al. 2007:106). Indeed, Van Huyssteen views dissensus as a positive and constructive part of pluralism in the dialogue between theology and science (2006a:33). 
1989 they were dedicated to dialogue, leadership, and cultural change.

- Chris Moore and his colleagues at CDR Associates as significant developers of the 'Alternatives to Violence Project' (AVP) in 1975. The project relates to alternative methods of conflict-/or dispute resolution.

\section{The 'call to adventure' in the 1970s}

The idea of a 'call to adventure' is in story construction associated with Christopher Vogler and Joseph Campbell (cf. Vogler 1999; cf. Campbell 1972); it signifies that something has happened that calls a particular journey into motion. Fairly recently the period and social movements of the 1970s seem to have had a profound impact on many developments. The major consequence was a broad move towards awareness of diversity (stemming from the recognition of the individual), equality, and participation.

While reflecting on the institution of marriage, Doherty (2002:21) mentions that the 1960s and 1970s brought about all kinds of movements and revolutions: foremost the sexual revolution, the divorce revolution, and the feminist movement; added to this are the anti-authority movements such as against the Vietnam War; the psychological revolution and a strong rhetoric of individualism.

With regard to the notion of neutrality that is of special importance to facilitation, Koppelman (2004:635), notes that the 1970s also saw the emergence of the neutrality theory. This happened simultaneously with controversies over abortion, gay rights, funding for the arts, child-care policy, the roles of the sexes, and the place of traditional values in education, especially in sex education (Koppelman 2004:635).

In respect of facilitation, Doyle (2007:xiii) refers to a movement toward nascent human potential in the 1960s and 1970s. In this movement learning facilitators - also referred to as awareness facilitators - their role finding particular expression in what came to be known as meeting facilitation, had an important influence (Doyle 2007:xiii). According to Doyle (2007:xiii) facilitation shares the philosophy, mind-set, and skills of people from nonviolent, and other movements over the centuries. Examples that are provided include the women's consciousness-raising movements, civil rights movement, and people such as Gandhi, and Martin Luther King, Jr.

From the aforementioned nebulas social milieu, taskoriented group facilitation developed over thirty years and can especially be linked to industrial and information-rich societies (Doyle 2007:xiii). Facilitation found very concrete expression in the corporate or business sector. Hunter et al. (2007:20) indicate that facilitation first became associated with this context, during the 1980s and 1990s, through the 'total quality movement' (TQM): a step by step improvement with a focus on teamwork as a means of dealing adequately with rapid change, complexity and advances in technology, and by considering organisational processes, as for example, strategic planning, performance management and public consultation.

All of these examples, right from the earliest times, involve a person who stands in relation to the collective, be it, for example, a tribe, movement, or institution. Conventional practitioner facilitation has us believe that this person, the facilitator, can be neutral. This is a contested topic (Thomas 2010:240), one that we contest on epistemological grounds.

In the broader discussion, neutrality is a crucial theme for the practical theologian especially, when he or she might want to take up a facilitative role or frame of reference. It is one of the important reasons why we underline the narrative dimension of the individual life in relation to our theologies. In this, a facilitative approach takes a very different point of departure than what one might encounter with theologian's motivations for public theology. Our motivation aligns with Ralph Waldo Emerson (2003:153) asserting that 'there is properly no history; only biography.'

\section{Storied practical theology}

Facilitator Michael Doyle (2007) believes that society is starting to come full circle:

from the circle of the tribe around the fire, to the pyramidal structures of the last 3000 years, back to the ecology of the circle, flat pyramids, and networks of today's organizations. (p. xiii)

This is also true of theological development and therefore the growing importance of the role of life stories in theology. In his book Biography as Theology: How life stories can remake today's theology, James McClendon uses the concept of 'story theology' (1974:188-201).

Stories are not only the means through which we give expression to our experiences; they are first and foremost the means through which we construct our experiences and our realities (Day Sclater 2003:317). Through the process of languaging we form our stories, but in the same process we are formed by our stories. It is a never-ending process of storying and becoming, becoming and storying. We story our theology and in the same process we are theologically storied.

Day Sclater (2003:321) refers to the 'three crucial aspects of narrative as identity', which make it clear why theology, story, and identity are so inseparable and integrated:

- Firstly there is a moral aspect. To share a personal story is to position oneself in terms of morality. Human morality is deeply narrative in character (cf. Barbieri 1998).

- There is also a social and cultural dimension, and therefore a story is a social, or interpersonal construct:

To narrate is to assume or imagine an audience but it is also more than that -it is to engage as a self, as an active, interpretive human agent, with others and with the world. (Day Sclater 2003:321)

In this ongoing identity work we are dependent on the potential or transitional space in which aspects of the self can be created and transformed in relationships with 
others and within the matrices of culture (Day Sclater 2003:326).

- It is through the process of storying that we are challenged to take up responsibility. We are embodied human beings and therefore embedded in our stories. Yet, it is through the process of storying that we can take ownership of our stories (wherein our acts and moral self are inseparable) (cf. Barbieri 1998:373).

This transitional space, which Day Sclater (2003:326) refers to, is a key concept for the understanding of theology as biography:

To tell one's story is to occupy such a transitional space ... The story provides an intermediate or transitional area of experience in which the self continually negotiates its position in the world, inscribes itself in relation to the available cultural scripts, integrates past, present and future through acts of remembering and telling. (Day Sclater 2003:327)

This transitional space, created in and through the narrative process, is also related to the safe, but fragile public space which, according to Van Huyssteen (2006b:148) is the result of an interdisciplinary discourse. Van Huyssteen uses the term wide reflective equilibrium to point to the optimal, but fragile communal understanding we are capable of at any given moment in time. A postfoundationalist notion of reality enables us to communicate across boundaries and move transversally from context to context, from one tradition to another, from one discipline to another. He continues that in this wide reflective equilibrium, we finally find the safe but fragile public space we have been searching for, a space for shuttling back and forth between deep personal convictions and the principles that finally result from interpersonal judgements.

This process of shuttling back and forth can also be described with narrative terminology. It refers to the socialconstructionist process of the telling and retelling of stories. It consists of the sharing of one's own story and the listening to others' stories, with the possibility of a retelling and therefore re-authoring of stories.

The paradoxical concept of 'safe but fragile' indeed becomes an inviting, but dangerous territory in trying to find a balance between the personal and the public for the theologian. The transitional space of storying can be understood in both a negative and positive way. In the all too familiar world of theological certainty and domination, it might be a very unsafe space for the sharing of personal theological stories.

We agree with Jacobs (2003:25) that narrative theology has the potential, but is also challenged to create a bridge between the meta-narratives of church and theology on the one side, and individual lifestories on the other side. On the one hand the corporative story provides the safety and space for the individual story to be embedded into a bigger context; on the other hand there is the danger of a discourse becoming so dominant that it leaves no space for the development of personal stories. When the narrative integrity of a given single life is not accepted and respected the space can become more fragile than safe. The problem, as seen by Jacobs, is that church theologians can be more concerned with 'the narrative coherence (or incoherence) of whole traditions', than with 'what makes a human life coherent' (Jacobs 2003:25).

A theology that allows for personal stories and takes them seriously, has the potential to be relevant and authentic, and therefore to be public theology. In the words of Adeney (2009:169): 'studying biographies helps to create a shift in consciousness that allows more complex theories to become conscious and useful.'

The narrative theological paradigm therefore makes it possible to regard the human life as a work of art that is constantly created in the in-between of different worlds. The human life is a storying artwork that takes shape within the network of stories. The words of Ellis and Bochner (1996) about ethnography are also applicable to this new understanding of practical theology and the practical theologian:

It is interested in depth of quality and approaches the lives of people as 'works of art'. It is therefore interested in real persons people with smells, tastes, desires, and thoughts. The implication is that the metaphor best suited for the researcher is that of an artist. (p. 18)

The emphasis is on the uniqueness of each researcher, and therefore on the surprising possibilities of a specific research story.

To pursue practical theology within this line of thought, requires intellectual and emotional flexibility, which includes the assumption that practical theologians are in touch with their own stories and aware of the autobiographical embeddedness of their theological convictions. Such awareness goes hand in hand with finding oneself, and inventing oneself in the safe, but fragile public space. This finding of oneself can even be described as constructing oneself. You cannot know your theology, unless you first narrate the tales of its becoming, 'the stories of its genesis' (cf. Kearney [1988] 1994:17). ${ }^{6}$ The task of the autobiography is in this sense not a luxury for the theologian, but a necessity not only for the understanding of one's own theology, but mainly for the construction of it.

This safe, but fragile public space can also be described with the metaphor of the ecotone. The ecotone - which is a transition area between adjacent, but different plant communities - can be used as a metaphor for the description of the nature of practical theology. The following quotation explains this unique and challenging territory:

The ecotone represents a shift in dominance. Ecotones are particularly significant for mobile animals, as they can exploit more than one set of habitats within a short distance. The ecotone contains not only species common to communities on both sides; it may also include a number of highly adaptable species that tend to colonize such transitional areas. (Wikipedia n.d.)

6.Kearney writes about 'imagination', but the same is true of the knowing of any concept or idea. 
Practical theologians should be such 'highly adaptable' practitioners. But, in order to develop into this kind of practical theologian, some of us will need to make a major paradigm shift. It requires a shift away from a foundational understanding of theology to a postfoundational, and therefore narrative understanding.

The ecotone seems to be a powerful metaphor for a postfoundational practical theology. The practical theologian who operates in and from this paradigm, finds him- or herself in the safe, but fragile public space created in interdisciplinary dialogue. Such a practical theology is involved with an increased diversity of narratives. In and through these narratives more than one set of habitats are visited and revisited.

The only credible way of visiting such other habitats or narratives is with and through the personal story. If other life stories are regarded as works of art, the implication is for practical theologians, researchers, or facilitators to regard themselves in the same way. These other stories cannot be visited with the illusion that the researcher ${ }^{7}$ is objective and untouched. To the contrary, when other stories are visited, risky steps are taken and one cannot avoid the sharing of one's personal story. ${ }^{8}$ But given the notion of an artwork, it is not only risky, but also very empowering. It is to become aware of being part of a network of stories and being drawn into the weaving of a bigger picture or work of art as it relates to facilitation, research and other roles - indeed a safe, but fragile public space.

\section{The inscribed facilitator}

It is not in the least only the facilitator's story that matters but also the telling and retelling of those in facilitation those with whom the facilitator shares the fragile but safe space. The story telling includes also the collaborative construction of the story of the movement or organisation (i.e. the dialogical context or habitat). The facilitator and other participants find themselves embedded in a network of stories that are collaboratively shaped. The religious and/ or spiritual dimension is ever part of this telling and retelling in the shaping of reality. The facilitator finds him- or herself in a gallery of living art where the works of art also find a particular expression collectively that is different from expressions found in other galleries. Visiting this art gallery and individual works of art creates a potential to accomplish whatever it is that we hope to achieve together in facilitation. In terms of our own focus as well, we agree with Rorty, who would have us understand of philosophy that its function is not to arbitrate truth but to tell stories (Robbins 2011:xiixiii): with pursuing philosophy, like telling stories, there is a 'shared ability to appreciate the power of redescribing, the power of language to make new and different things possible and important' (Rorty 1989:39; cf. Robbins 2011:xii-xiii).

7.The role of researcher is here in question as it relates to Ellis and Bochner writing about research but it can also be said of the facilitator.

8.See as examples Müller (2009, 2011a).

\section{What informs the inscribed facilitator?}

The idea of being inscribed has relevance in particular ways. It firstly relates to the narrative dimension of our lives, and in relation to practical theology, particularly in the manner as set out above (cf. 'Storied practical theology'). Naturally it also relates to the way in which interdisciplinary dialogue shapes us and is shaped by us.

Along with Freedman and Combs (1996), our preference for narrative practice (e.g. research, therapy, inquiry, coaching and facilitation) derives from the way in which narratives organise and maintain our lives (Freedman \& Combs 1996:29-33). Some authors have worked with narrative as an organising metaphor for a number of years (both in the humanities and social sciences), before narrative ideas began to be used in the field of therapy (the context in which Freedman \& Combs [1996] write). Amongst the authors they refer to include: E. Bruner (1986) Ethnography as narrative; J. Bruner (1986) Actual minds, possible worlds; and Geertz (1983) Local knowledge: Further essays in interpretive anthropology (Freedman \& Combs 1996:29-33).

By inscribed we do not mean to imply passivity. On the contrary, telling our stories involves activity (i.e. construction) but we do this by interpretively weaving together an inner envelope that consists of our past life experiences, our current situatedness and our anticipation of the future. We also do this set against an outer envelope that involves the broader social milieu and socially constructed realities. Irrespective of whatever rationalities might be part of facilitation, they all already form part of a reality that is socially constructed. On a sociological level, these realities are formed along the lines of subjectification, externalisation, objectification (which consists of typification, institutionalisation, and legitimisation), and internalisation (Arbnor \& Bjerke 2009:144-148; cf. Freedman \& Combs 1996:23-27).

Secondly, interdisciplinary dialogue consists of a duet and not a duel. ${ }^{9}$ In this sense it is natural that one of the ways in which the inscribed facilitator is informed would be different aspects that the duet partner contributes. A narrative approach concurs with facilitative traditions, for example those that try to instil a 'respectful, accepting culture, deep embodied listening, the ability to be in silence together, the willingness to speak from one's own experience or knowing, and the willingness to suspend judgments' (Hunter et al. 2007:98). This is also called a sacred space (Hunter et al. 2007:98), which resonates with the reference to a transitional space mentioned earlier. Narrative practice further corresponds to what Arbnor and Bjerke (2009:18-19) refer to as the basic criteria of any inquiry (their context of inquiry notably that of business methodology), namely, awareness and self-reflection. Although a word of caution at this stage: it is not a matter of becoming aware rather than in reflecting and becoming aware, one is busy constructing or inventing - Rorty notes that we tend to think of causes as discovered 9.To borrow from Wentzel van Huyssteen's work (1998), Duet or duel? Theology and science in a postmodern world. 
rather than invented (1989:28). The prominence of narrative also relates to ideas such as appreciative inquiry often used in the corporate environment. We gather from Rodas-Meeker and Meeker (2005:99) that appreciate inquiry (AI) as they employ it in facilitation, is a process relevant in probing the history and stories of an organisation. In relation to narrative therapy, Freedman and Combs (1996:15-16) mention that in their time, interventions were aimed at specific problems and goals, but, having listened to Michael White, they no longer tried to solve problems. Rather they became interested in bringing forth and 'thicken' (with reference to Geertz [1978]) stories that did not support or sustain problems. On this account $\mathrm{AI}$ and narrative therapy has the same intention, and therefore the same intention as a facilitative approach regarding practical theology. A facilitative approach in, and to, practical theology (with reference to its narrative accent) also relates to the following aspects that some emphasise in facilitation. It resonates with Miki Kashtan's ideas behind the art of transparent facilitation (2005); with Mike Brown $(2002,2003,2004)$ on the masking of power and social order; with regard to neutrality, with those who contest it, such as Cheryl Estes (2004), Phil Kirk and Mike Broussine (2000); and with reference to epistemology, Cheryl Estes (2004); with Roger Schwarz (2002) on different hats to be worn deemed necessary in facilitation; and with James Troxel (2005) regarding affirmative facilitation and process consultation. The dimensions of education in facilitator training that Thomas (2008:169) discusses are also useful in plotting oneself within the genre of facilitation.

It is important to note that little of the initial literature review, including those genres that Thomas mentions (2008), relate overtly and adequately to what postfoundational, social constructionist, and narrative dimensions entail. Therefore, this is what a facilitative approach regarding practical theology will contribute to the duet. It is the acknowledgement and reliance on particular accents in one's own tradition that imbue the interdisciplinary dialogue with a sense of agency. To illustrate: for the facilitative consulting role (that is part of practical theological facilitation), one might draw from larger conceptual frameworks of practical theology that underscore different approaches in one design. See, for example, De Roest (1998:25) who mentions Browning, Mette, Van der Ven; Heitink (1993:223-226); Dingemans (1996) and Osmer $(2008,2011)$. Then, as referred to earlier, the discipline's current DNA, that of action or practice and an interpretive turn, contribute significantly to the dialogue with facilitation. Lastly, as it relates to certain traditions within the broad DNA, one might rely on post-structural accents such as social constructionism, postfoundationalism and narrative practice. For example, there was not only an interpretive turn (i.e. part of the current practical theological DNA) but in that, a further narrative turn in practical theology (cf. Demasure \& Müller 2006). These are accentuations that are particularly helpful.

\section{Closing remarks}

A facilitative approach as it pertains to practical theology invites us to look again through both the microscope and the telescope; though, in the case of the prior not with its 17th century connotation of scientific reductionism (Midgley 2004).

It brings under the microscope a focus on the individual (with reference to being inscribed, unavoidably influential, opting for a decentred position), and individual life stories with tremendous potential for intersubjectivity and verisimilitude. The reference to the individual incorporates the narrated life of the practical theologian as facilitator and the ways that he or she is inscribed. It entails a shift in focus from that of practical theology to the practical theologian. If the person then becomes important, it is also important how that person comes across, engages, and relates to an audience. In this regard we emphasise a decentred role.

Simultaneously and strangely enough when focusing on the individual, it also implies looking through the telescope, bringing into view potential far off contexts and audiences that relate to the stories being told. The horizon of practical theology then opens up both in terms of (1) its agenda (be it in domains, such as, ecology, politics, or socio-economics); (2) its audience (ministry, academia, society); (3) in its ways (attitude, methodologies) of working alongside other disciplines; and (4) with the acknowledgement of different shapes of our human rationality (such as may be found in e.g. philosophy, psychology, or economic and management sciences).

Do these metaphors - microscope and telescope - constitute yet another dualism? It certainly is not intended to do so. It rather involves the recognition that, as Mottier (2005) notes, referring Heidegger, 'being cannot be dissociated from beingin-the-world.' Or, as Tracy mentions about new ecumenism, the universal is to be found by embracing the particular (1994:138). In likewise fashion Debray comments (2008:35): 'The appearance of localisms does not negate globalization. On the contrary, it is a product of globalization.'

From a social constructionist perspective, we view the individual as a member of a tribe, but a member that has a particular narrative. The particular (also the 'local' as opposed to the universal, 'oral' as opposed to text, and 'timely' as opposed to timeless) relate to what Toulmin (1988:338) has named the neglected half of the philosophical field from the 17th century, namely practical philosophy. If the measure of the 'particular' is par excellence a matter of practical philosophy, then the 'particularity' of the practical theologian, of the way in which the facilitator is inscribed, constitutes in exemplary fashion the discipline as practical theology.

\section{Acknowledgements Competing interests}

The authors declare that they have no financial or personal relationship(s) which may have adversely affected the writing of the article.

\section{References}

Adeney, F.S., 2009, 'Why Biography? Contributions of Narrative Studies to Mission: Theology and Mission Theory', Mission Studies 26, 153-172. http://dx.doi.org/10 .1163/016897809X12548912398758 
Anderson, R.S., 2001, The shape of practical theology: Empowering ministry with theological praxis, InterVarsity Press, Downers Grove, IL.

Arbnor, I. \& Bjerke, B., 2009, Methodology for creating business knowledge, 3rd edn. SAGE, London.

Barbieri, W.A. Jr, 1998, 'Ethics and the Narrated Life', The Journal of Religion 78(3), 361-386. http://dx.doi.org/10.1086/490234

Bens, I., 2005, Facilitating with ease: Core skills for facilitators, team leaders and members, managers, consultants, and trainers, 2nd edn., Jossey-Bass, San Francisco, CA. PMCid:1665473

Brown, M., 2002, 'The Facilitator as Gatekeeper: A Critical Analysis of Social Order in Facilitation Sessions', Journal of Adventure Education and Outdoor Learning 2(2), 101-112. http://dx.doi.org/10.1080/14729670285200211

Brown, M., 2003, 'Paraphrases and summaries: A means of clarification or a vehicle for articulating a preferred version of student account?', Australian Journal of Outdoor Education 7(2), 25-33.

Brown, M., 2004, “Let's go round the circle:" How Verbal Facilitation Can Function as a Means of Direct Instruction', Journal of Experiential Education 27(2), 161-175.

Browning, D.S. (ed.), 1983, Practical Theology, Harper and Row, San Francisco, CA.

Browning, D.S., 1991, A fundamental practical theology: Descriptive and strategic proposals, Fortress Press, Minneapolis, MN.

Bruner, E.M., 1986, 'Ethnography as narrative', in V.W. Turner \& E.M. Bruner (eds.), The Anthropology of Experience, pp. 139-155, University of Illinois Press, Urbana, IL.

Bruner, J., 1986, Actual minds, possible worlds, Harvard University Press, Cambridge, MA.

Campbell, J., 1972, The hero with a thousand faces, Princeton Univeristy Press, Princeton, NJ.

Day Sclater, S., 2003, 'What is the Subject?', Narrative Inquiry 13(2), 317-330. http:// dx.doi.org/10.1075/ni.13.2.05day

De Bono, E., n.d., Edward de Bono: Father of Lateral Thinking, viewed 13 June 2012, from http://www.edwdebono.com.

De Bono, E., 1973, Lateral Thinking: Creativity step by step, Harper Colophon, New York.

De Bono, E., 1999, Six thinking hats, rev. \& updated edn., Back Bay Books, New York, NY.

De Roest, H., 1998, Communicative identity: Habermas' perspectives of discourse as a support for practical theology, Uitgeverij Kok, Kampen.

Debray, G., 2008, 'Secularism's Crisis of Faith: God and the Political Planet', New Perspectives Quarterly 25(4), 33-55. http://dx.doi.org/10.1111/j.1540-5842. 2008.01019.x

Demasure, K. \& Müller, J., 2006, 'Perspectives in Support of the Narrative Turn in Pastoral Care', Nederduitse Gereformeerde Teologiese Tydskrif 47(3/4), 410-419.

Dingemans, G.D.J, 1996, 'Practical Theology in the Academy: A contemporary Overview', The Journal of Religion 76(1), 82-96. http://dx.doi.org/10.1086/489737

Doherty, W.J., 2002, 'Where are we and how did we get here?' in K. Anderson, D. Browning \& B. Boyer (eds.), Marriage. Just a piece of paper?, pp. 20-24, William B. Eerdmans, Grand Rapids. PMid:12271550

Doyle, M., 2007, 'Forward by Michael Doyle', in S. Kraner (ed.), Facilitator's quide to participatory decision-making, 2nd edn., pp. xi-xvi, Jossey-Bass, San Francisco, CA.

Ellis, C. \& Bochner, A.P. (eds.), 1996, Composing Ethnography: Alternative forms of qualitative writing, SAGE, London.

Emerson, R.W., 2003, Nature and selected essays, Reissue edn., Penguin Classics, London.

Estes, C., 2004, 'Promoting student-centered learning in experiential education', Journal of Experiential Education 27(2), 141-160.

Freedman, J. \& Combs, G., 1996, Narrative therapy: The social construction of preferred realities, W.W. Norton and Company, New York, NY.

Geertz, C., 1978, The interpretation of cultures, Basic Books, New York, NY.

Geertz, C., 1983, Local knowledge: Further essays in interpretive anthropology, Basic Books, New York, NY.

Gergen, K. J., 2009, An invitation to social construction, 2nd edn., SAGE, London.

Grippe, E., 2006, Richard Rorty (1931-2007), viewed 08 June 2012, from http://www. iep.utm.edu/rorty/.

Gross, N., 2008, Richard Rorty: The making of and American philosopher, University of Chicago Press, Chicago, IL.

Heitink, G., 1993, Praktishe Theologie: Geschiedenis, theorie, handelingsvelden Uitgeverij Kok, Kampen. PMid:8333911

Hogan, C., 2005, 'Successfully facilitating multicultural groups', in S. Schuman (ed.) The IAF handbook of group facilitation, pp. 255-280, Jossey-Bass, San Francisco, CA.

Hunter, D., Bailey, A. \& Taylor, B., 1995, The art of facilitation, Fisher Books, Pennsylvania, PA.

Hunter, D., Thorpe, S., Brown, H. \& Bailey, A., 2007, The art of facilitation: The essentials for leading great meetings and creating group synergy, Jossey-Bass, San Francisco, CA. http://dx.doi.org/10.1057/palgrave.ijea.2150074

Jacobs, A., 2003, 'What narrative theology forgot', First Things, August/September 25-30.

Kashtan, M., 2005, 'The gift of self: The art of transparent facilitation', in S. Schuman (ed.) The IAF handbook of group facilitation, pp. 573-590, Jossey-Bass, San Francisco, CA

Kearney, R. [1988] 1994, The wake of imagination, Routledge, New York, NY. http:// dx.doi.org/10.4324/9780203430620

Kiiti, N. \& Nielsen, E., 1999, 'Facilitator or Advocate: What's the Difference?', in S.A. White (ed.), The art of facilitating participation: Releasing the power of grassroots communication, pp. 52-76, SAGE, New Delhi.
Kirk, P. \& Broussine, M., 2000, 'The Politics of Facilitation', Journal of Workplace Learning 12(1), 13-22. http://dx.doi.org/10.1108/13665620010309756

Koppelman, A., 2004, 'The Fluidity of Neutrality', Review of Politics 66(4), 633-648. http://dx.doi.org/10.1017/S0034670500039917

McClendon, J.W. Jr, 1974, Biography as theology: How life stories can remake today's theology, Abingdon Press, Nashville, TN. PMid:4151901

Midgley, M., 2004, The myths we live by, Routledge, London.

Mottier, V., 2005, 'The Interpretive Turn: History, Memory, and Storage in Qualitative Research', Forum: Qualitative Social Research/Sozialforschung 6(2), Art. \#33, viewed 29 October 2012, from http://nbn-resolving.de/urn:nbn:de:0114fqs0502330

Müller, J.C., 2004, 'HIV/AIDS, Practical Theology, and Postfoundationalism: The emergence of a new story', Hervormde Teologiese Studies 60(1/2), 293-306.

Müller, J.C., 2009, “'Tussen-in en duskant geloof"', in By se Bedkassieboek, bl. 136-145, Nasionale Boekhandel, Kaapstad.

Müller, J.C., 2011a, Om te mag twyfel, Tafelberg, Kaapstad. http://dx.doi.org/10.1016/ j.sbspro.2011.01.029

Müller, J.C., 2011b, 'Postfoundational practical theology for a time of transition', HTS Teologiese Studies/Theological Studies 67(1), Art. \#837, 5 pages. http://dx.doi. org/10.4102/hts.v67i1.837

Osmer, R.R., 2008, Practical theology: An introduction, Eerdmans, Grand Rapids, MI.

Osmer, R.R., 2011, 'Practical theology: A current international perspective', HTS Teologiese Studies/ Theological Studies 67(2), \#Art. 1058, 7 pages. http://dx.doi. org/10.4102/hts.v67i2.1058

Osmer, R.R. \& Schweitzer, F.L. (eds.), 2003, Developing a public faith. New directions in practical theology. Essays in honor of James W. Fowler, Chalice Press, St. Louis, MO.

Pienaar, H.E., 2012, 'Overture to Practical Theological Facilitation', Nederduitse Gereformeerde Teologies Tydskrif 53(3/4)

Robbins, J.W., 2011, 'Richard Rorty: A philosophical guide to talking about religion', in R. Rorty (ed.), An ethics for today, pp. vii-xxii, Columbia University Press, New York, NY.

Rodas-Meeker, M.B. \& Meeker, L., 2005, 'Building Trust: The Great Enabler', in S Schuman (ed.), The IAF handbook of group facilitation, pp. 89-102, Jossey-Bass, San Francisco, CA.

Rorty, R., 1989, Contingency, irony and solidarity, Cambridge University Press, Cambridge. http://dx.doi.org/10.1017/CBO9780511804397, PMid:2600064

Schwarz, R., 2002, The skilled facilitator: A comprehensive resource for consultants, facilitators, managers, trainers, and coaches, Jossey-Bass, San Francisco, CA.

Thomas, G., 2008, 'Facilitate First Thyself: The Person-Centered Dimension of Facilitator Education', Journal of Experiential Education 31(2), 168-188. http:// dx.doi.org/10.5193/JEE.31.2.168

Thomas, G., 2010, 'Facilitator, Teacher, or Leader? Managing Conflicting Roles in Outdoor Education', Journal of Experiential Education 32(3), 239-254. http:// dx.doi.org/10.5193/JEE.32.3.239

Toulmin, S., 1988, 'The Recovery of Practical Philosophy', America Scholar 57(3), $337-353$

Tracy, D., 1994, On naming the present: Reflections on God, hermeneutics, and church, Orbis books, New York, NY.

Tracy, D., 1998, The analogical imagination: Christian theology and the culture of pluralism, The Crossroad Publishing Company, New York, NY.

Troxel, J.P., 2005, 'Affirmative facilitation: An asset-based approach to process consultation', in S. Schuman (ed), The IAF handbook of group facilitation, pp. consultation', in S. Schuman (ed.), The IAF
591-608, Jossey-Bass, San Francisco, CA.

Van Huyssteen, J.W., 1998, Duet or duel? Theology and science in a postmodern world SCM Press, Norwich. http://dx.doi.org/10.1177/004057369805500206

Van Huyssteen, J.W., 1999, The shaping of rationality: Toward interdisciplinarity in theology and science, Eerdmans, Grand Rapids, MI. PMid:10615973

Van Huyssteen, J.W., 2000, 'Postfoundationalism and interdisciplinarity, A response to Jerome Stone', Zygon 35(2), 427-439. http://dx.doi.org/10.1111/05912385.00285

Van Huyssteen, J.W., 2006a, Alone in the world? Human uniqueness in science and theology: The Gifford Lectures, Eerdmans Publishing Co., Grand Rapids, MI. PMid:16645122

Van Huyssteen, J.W., 2006b, 'When our bodies do the thinking: Theology and Science Converge', American Journal of Theology \& Philosophy 27(2), 127-153.

Van Huyssteen, J.W., n.d, J. Wentzel van Huyssteen, viewed 29 October 2012, from http://www.vanhuyssteen.org/

Vattimo, G., 2011, 'Introduction', in R. Rorty (ed.), An ethics for today, pp. 1-6, Columbia University Press, New York, NY.

Vogler, C., 1999, The writers journey: Mythic structure for storytellers and screenwriters, 2nd edn., PAN Books, London.

Wallace, R.J., 2009, 'Practical Reason', in E.N. Zalta (ed.), The Stanford Encyclopedia of Philosophy (Summer 2009 edition), viewed 06 June 2012, from http://plato. stanford.edu/archives/sum2009/entries/practical-reason/

Westphal, K.R., 2011, 'Practical reason: Categorical imperative, maxims, laws', in W. Dudley \& K. Engelhard (ed.), Immanuel Kant: Key concepts, pp. 103-119, Acumen, Durham.

White, B., 2007, 'Clifford Geertz: Singular Genius of Interpretive Anthropology', Development and Change 38(6), 1187-1208. http://dx.doi.org/10.1111/j.14677660.2007.00460.x

Wikipedia n.d., s.v. Ecotone, viewed 25 March 2010, from http://en.wikipedia.org/ wiki/Ecotone 